\title{
SCIENTIFIC REPORTS

\section{Environmental and ecological factors mediate taxonomic composition and body size of polyplacophoran assemblages along the Peruvian Province}

\begin{abstract}
Christian M. Ibáñez $\mathbb{D}^{1 *}$, Melany Waldisperg ${ }^{2}$, Felipe I. Torres $\mathbb{D}^{1,3}$, Sergio A. Carrasco $\mathbb{D}^{4,5}$, Javier Sellanes $\mathbb{D}^{4,5}$, M. Cecilia Pardo-Gandarillas $\mathbb{D}^{3}$ \& Julia D. Sigwart $\mathbb{D}^{6}$

Intertidal communities' composition and diversity usually exhibit strong changes in relation to environmental gradients at different biogeographical scales. This study represents the first comprehensive diversity and composition description of polyplacophoran assemblages along the Peruvian Province (SE Pacific, $\left.12^{\circ} \mathrm{S}-39^{\circ} \mathrm{S}\right)$, as a model system for ecological latitudinal gradients. A total of 4,775 chitons from 21 species were collected on twelve localities along the Peruvian Province. This sampling allowed us to quantitatively estimate the relative abundance of the species in this assemblage, and to test whether chitons conform to elementary predictions of major biogeographic patterns such as a latitudinal diversity gradient. We found that the species composition supported the division of the province into three ecoregional faunal groups (i.e. Humboldtian, Central Chile, and Araucanian). Though chiton diversity did not follow a clear latitudinal gradient, changes in species composition were dominated by smaller scale variability in salinity and temperature. Body size significantly differed by ecoregions and species, indicating latitudinal size-structure assamblages. In some localities body size ratios differed from a random assemblage, evidencing competition at local scale. Changes in composition between ecoregions influence body size structure, and their overlapping produce vertical size segregation, suggesting that competition coupled with environmental conditions structure these assemblages.
\end{abstract}

Environmental factors (e.g. temperature, productivity) are the main drivers modulating latitudinal gradients of species richness at different spatial and temporal biogeographical scales ${ }^{1}$. Different ecological mechanisms have been suggested to underpin these gradients in species richness. One of them is the "competitive exclusion hypothesis", which predicts a positive relationship between primary productivity and species diversity, and may directly relate factors such as lower productivity, stress, and lack of resources, to the limited number of species that can survive in a specific environment ${ }^{2-4}$. Therefore, when productivity increases, species richness also increases until a point where it becomes regulated by intense competition, which can cause an important competitive exclusion ${ }^{2,3}$. Another possible explanation is the "species-energy hypothesis", which suggests that species with small populations are highly vulnerable to stochastic events; hence, species persistence over time would depend on their ability to maintain a stable minimum population ${ }^{1,5,6}$. An environment with higher productivity will be able to support more species with viable minimum populations ${ }^{7}$. One way to infer competition within communities is to evaluate the body size ratio between species, according to Hutchinson's hypothesis, which states that a minimum space between species is necessary for coexistence ${ }^{8}$. This approach has produced a huge number of ecological studies

${ }^{1}$ Departamento de Ecología y Biodiversidad, Facultad de Ciencias de la Vida, Universidad Andres Bello, Santiago, Chile. ${ }^{2}$ Departamento de Ecología, Facultad de Ciencias Biológicas, Pontificia Universidad Católica de Chile, Santiago, Chile. ${ }^{3}$ Departamento de Ciencias Ecológicas, Facultad de Ciencias, Universidad de Chile, Santiago, Chile. ${ }^{4}$ Departamento de Biología Marina, Facultad de Ciencias del Mar, Universidad Católica del Norte, Larrondo 1281, Coquimbo, Chile. ${ }^{5}$ Millennium Nucleus for Ecology and Sustainable Management of Oceanic Islands (ESMOI), Coquimbo, Chile. ${ }^{6}$ Marine Laboratory, Queen's University Belfast, Portaferry, N. Ireland. *email: ibanez.christian@ gmail.com 

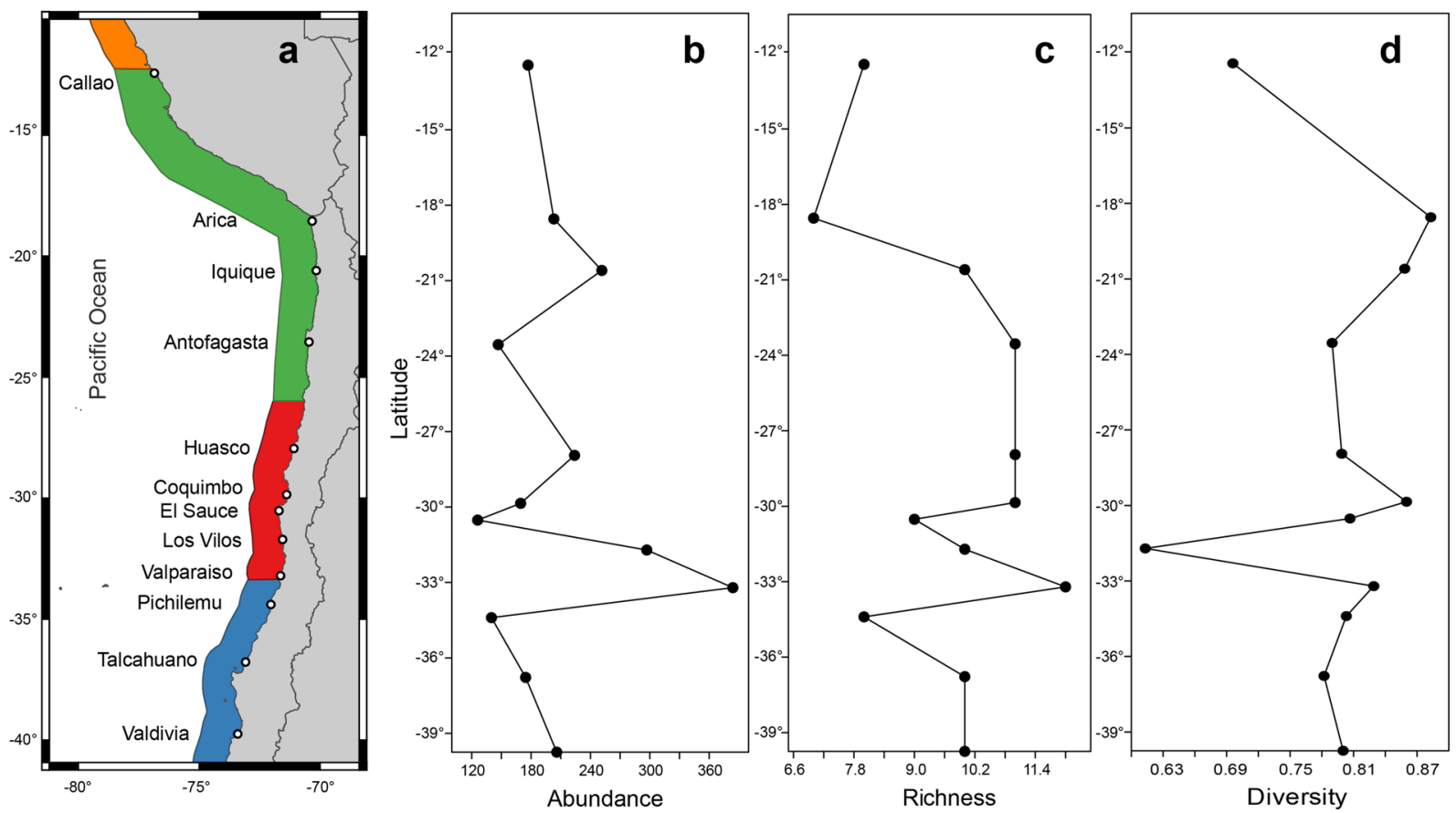

Figure 1. Sampling sites of polyplacophoran assemblages along 2,500 km of coast line in the Peruvian Province, from Callao, Peru $\left(12^{\circ} \mathrm{S}\right)$ to Valdivia, Chile $\left(39^{\circ} \mathrm{S}\right)$; (a) Map showing sampling sites and marine ecoregions represented by color areas in the coast-line (orange: Central Peru; green = Humboldtian; red = Central Chile; blue $=$ Araucanian) $(\mathbf{b})$ Relative abundance, (c) Species richness, and (d) Diversity.

searching for body size patterns of coexisting species ${ }^{9-11}$. Most controversy over statistical analyses of size overlap data (based on random assemblages) ${ }^{9,10}$ has been solved based on null models ${ }^{11}$.

The Southeastern Pacific (SEP) is composed of three biogeographic provinces: Panamian, Peruvian and Magellan ${ }^{12}$. The Peruvian Province, which extends from the Gulf of Guayaquil at $3^{\circ} \mathrm{S}$ to $42^{\circ} \mathrm{S}$ on the Chilean coast, is further subdivided in four recognised ecoregions (Central Peru, Humboldtian, Central Chile and Araucanian), where the marine species composition and richness is determined by oceanographic (e.g. temperature, productivity) and topographic features (e.g. coastal shelf area) ${ }^{13-18}$. One of the fundamental tenets of biogeography is the latitudinal diversity gradient: there are more species in the tropics ${ }^{19}$. Yet, a striking absence of clear latitudinal diversity patterns in the SEP have been found in different assamblages at the community level ${ }^{20-24}$, suggesting that the factors determining the distribution of organisms could be more prominently influenced by other factors, including both natural and anthropogenic drivers that locally modify oceanographic traits (e.g. upwelling zones, Ekman transport, and biogeographic transitions around $\left.30^{\circ} \mathrm{S}\right)\left(\mathrm{see}^{20,21}\right)$. This geographic variation in local richness of intertidal and subtidal communities along SEP exhibit a complex pattern, where areas of high and low species richness appear to be interspersed haphazardly ${ }^{21-23}$.

Much of the global data on biogeographic patterns comes from the study of molluscs, because of their ubiquity and deep fossil record ${ }^{25}$. Molluscs are also the most studied marine taxa in relation to gradients of species richness in the SEP; however, a large density of samples is required to test biogeographic hypotheses ${ }^{14,16,17,26,27}$. Within this group, the polyplacophorans, or chitons, stand out as important grazers in rocky intertidal habitats, capable of affecting the community structure due to their locally high abundances ${ }^{28-33}$. Chitons are exclusively marine animals, and many species are stenohaline $\mathrm{e}^{34,35}$, tolerating very low levels of salinity (e.g. Plaxiphora aurata in Chilean fjords) ${ }^{35,36}$. Therefore, it is possible that diversity and abundance of these species could be strongly influenced by local scale environmental factors, such as temperature and/or salinity. Another interesting pattern is the vertical segregation in size structure in intertidal habitats, where small chiton species and small individuals of larger species are found at higher habitats, whereas larger species occur at lower levels in rocky shores ${ }^{37}$.

The present study aims to describe and quantify for the first time the diversity (richness and abundance) and composition of polyplacophoran asemblages along 2,500 km of coast in the Peruvian Province to: 1) compare their faunistic similarities/differences among ecoregions, 2) evaluate the associations between diversity and environmental variables, and 3) evaluate potential size segregation by inter-specific competition through comparisons with null models of body size ratios. Considering the above, we hypothesize that environmental factors, and the effect of spatial competition, could determine the body size and distribution limits of chitons along the coasts of the South-eastern Pacific Ocean, generating a latitudinal gradient in species composition and diversity.

\section{Results}

A total of 4,775 chitons belonging to 21 species were collected on 12 localities along the Peruvian Province (Fig. 1a). The most abundant species corresponded to Chiton cumingsii (relative abundance, RA $=64$ chitons/ hours/persons), C. granosus ( $\mathrm{RA}=26)$, Tonicia fremblyana $(\mathrm{RA}=65)$, T. calbucensis $(\mathrm{RA}=24)$, C. magnificus $(\mathrm{RA}=17)$ (Fig. 2b-e,h, respectively), Acanthopleura echinata $(\mathrm{RA}=7.5)$ and Enoplochiton niger $(\mathrm{RA}=9.5)$ 


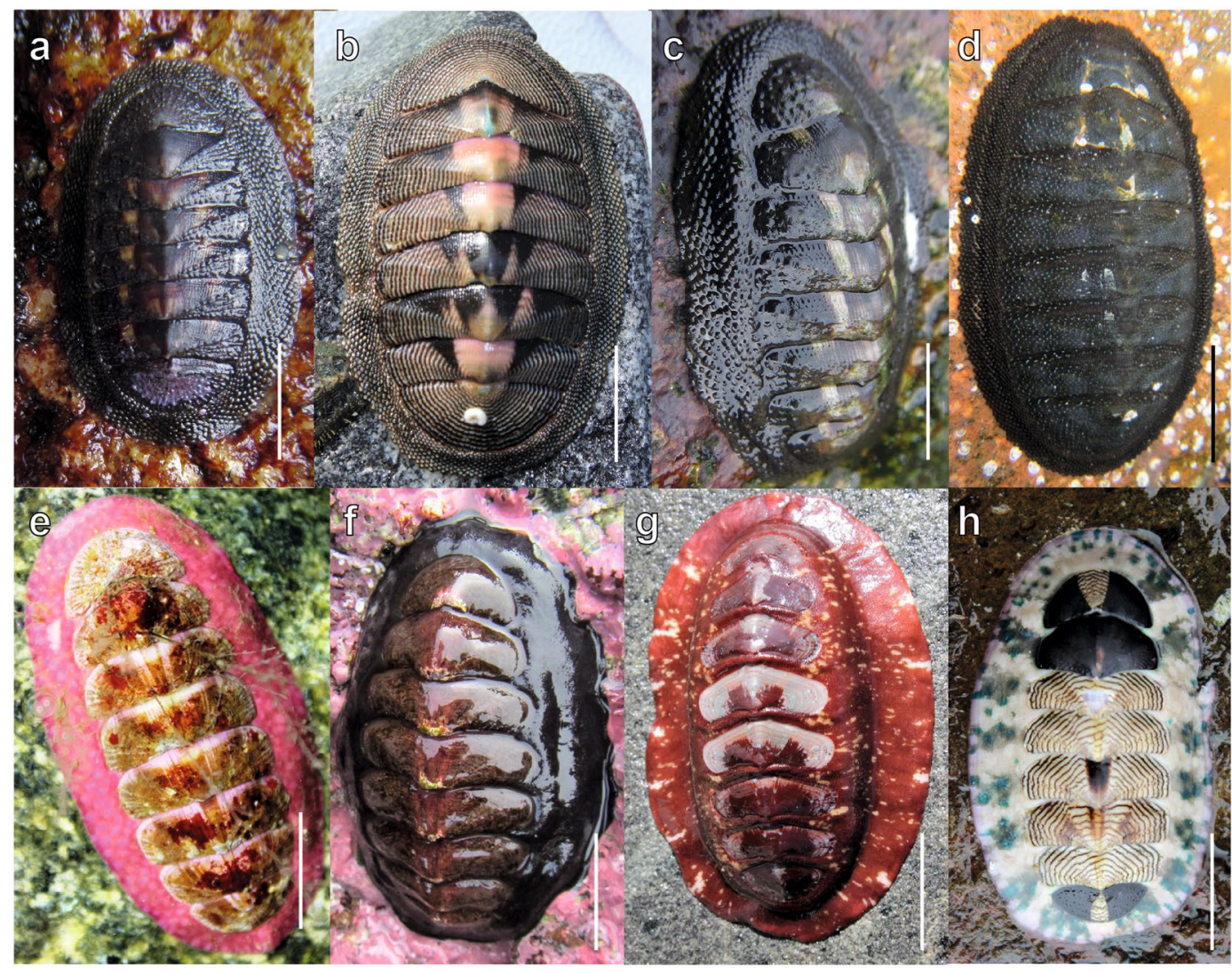

Figure 2. Chitons of the family Chitonidae found in the Peruvian Province; (a) Chiton barnesii (Coquimbo, scale bar $=20 \mathrm{~mm}$ ). (b) C. cumingsii (Coquimbo, scale bar $=10 \mathrm{~mm})$. (c) C. granosus (Valparaiso, scale bar $=10 \mathrm{~mm}$.) (d) C. magnificus (Valparaiso, scale bar $=20 \mathrm{~mm}$ ). (e) Tonicia calbucencis (Valdivia, scale bar $=5 \mathrm{~mm}$ ). (f) T. chilensis (Valparaiso, scale bar $=15 \mathrm{~mm})$. (g) T. disjuncta (Los Vilos, scale bar $=20 \mathrm{~mm})$. (h) T. fremblyana (Callao, scale bar $=10 \mathrm{~mm}$ ). Photographs credits: C.M. Ibáñez and M.C. Pardo-Gandarillas.

(Fig. 3a,b). Along the Peruvian Province, the highest abundances $(\mathrm{RA}=177)$ were observed in Callao (Peru), whereas the lowest $(\mathrm{RA}=32)$ were observed in El Sauce (Chile) (Table 1, Fig. 1b).

The rarefaction curves obtained for each locality showed a saturation around 50 RA, reached between 6 to 10 species (Fig. S1); therefore, the estimated richness based on the RA matrix was strong enough to represent the diversity of chitons (Fig. S1).

Chiton assemblages from the Peruvian Province had a comparatively high (and similar) diversity among localities, with around 7-12 species per site and higher local evenness rather than dominance of a single species (Table 1). In fact, in each ecoregion more than $60 \%$ of species are rare $(<10 \mathrm{RA}$, Table 1$)$. The assemblage of chitons found along the Peruvian Province evidenced the highest richness in Valparaiso (12 species), followed by Antofagasta, Huasco, Coquimbo (11 species), Iquique, Los Vilos, Talcahuano, Valdivia (10 species), El Sauce (9 species), Callao, Pichilemu (8 species) and finally Arica (7 species) (Table 1; Fig. 1c). The highest and lowest evenness $(J)$ were evidenced in Arica and Los Vilos, respectively (Table 1).

Beta diversity was relatively low at the intra-ecoregion level $(0.07-0.16)$ but higher among ecoregions (0.28-0.37; Fig. 4), suggesting a species replacement pattern related to distance (km) among sites (Fig. 5a). For example, Callistochiton pulchellus and Chaetopleura hennahi, Ischnochiton punctulatissimus and Tonicia swainsoni are unique in the Humboldtian ecoregion, while others were exclusive to the Araucanian ecoregion (e.g. Chaetopleura benaventei and Gallardoia valdiviensis). Despite positive value of the Mantel correlation coefficient $(r=0.53, P<0.001)$, the beta diversity did not evidence significant or consistent correlation to latitude $(r=-0.017, P=0.958$, Fig. 5b).

The species composition (Jaccard) carried out by the nMDS analysis, supported the existence of three faunal assemblages related to the different ecoregions (Fig. 6). A northern group between $12^{\circ} \mathrm{S}-24^{\circ} \mathrm{S}$ corresponding to the Humboldtian ecoregion (i.e. Callao, Arica, Iquique and Antofagasta; see Fig. 6). A second group between $27^{\circ} \mathrm{S}-34^{\circ} \mathrm{S}$ corresponding to the Central Chile ecoregion (i.e. Huasco, Coquimbo, El Sauce, Los Vilos and Valparaiso; Fig. 6). A third group between $34^{\circ} \mathrm{S}-40^{\circ} \mathrm{S}$ that conformed the Araucanian ecoregion (i.e. Pichilemu, Talcahuano and Valdivia; Fig. 6). Significant differences in species composition between ecoregions were found (PERMANOVA Jaccard, $F_{(2,9)}=5.104, P<0.001$ ), with SIMPER analysis evidencing the highest relative contributions of Chiton cumingsii, C. magnificus and C. granosus, the only three species with average relative abundances $>10 \%$ (Online Appendix Table S1, Fig. 2b-d, respectively). None of the diversity variables (species 


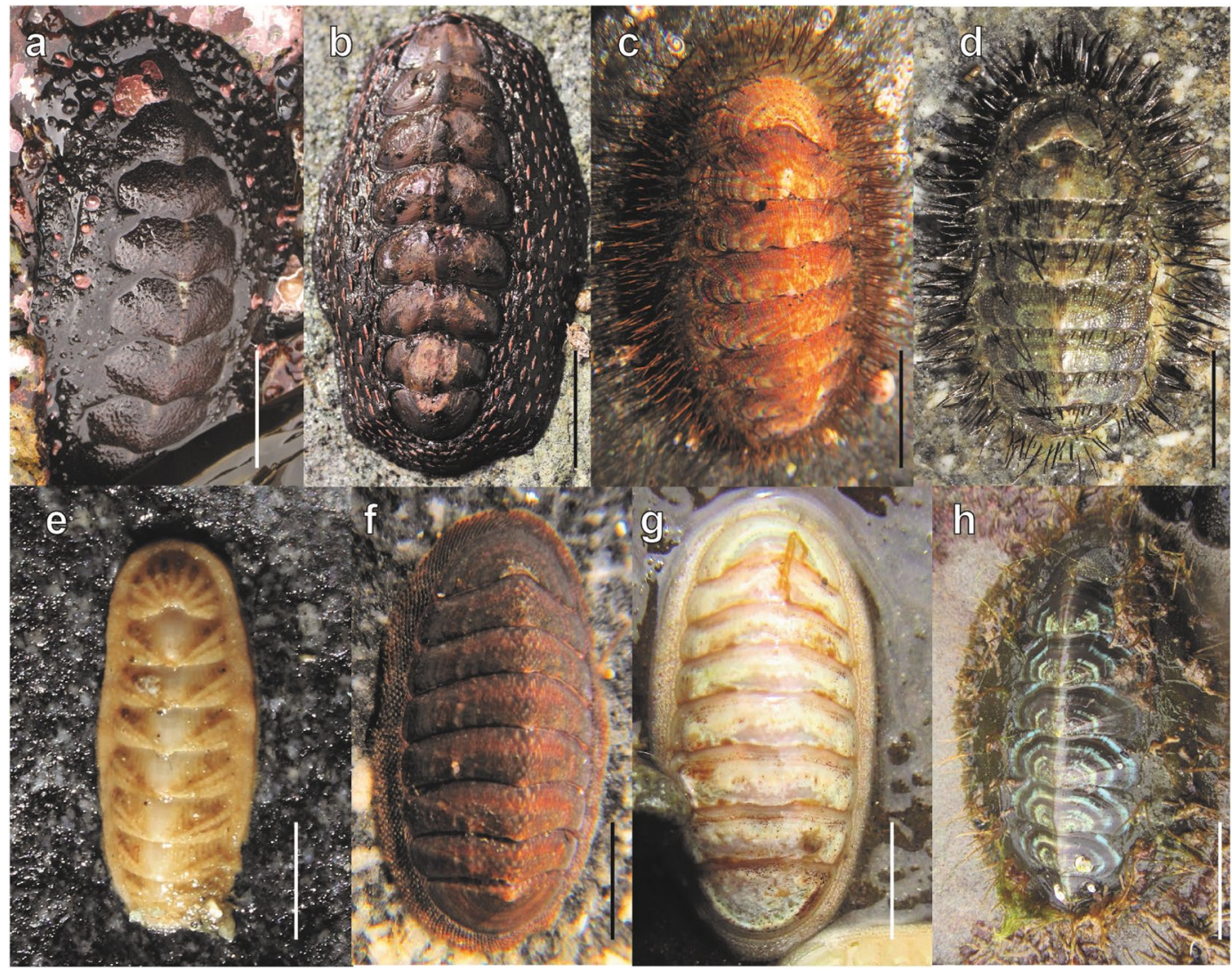

Figure 3. Chitons of the family Chitonidae, Chaetopleuridae, Callistoplacidae, Ischnochitonidae and Mopaliidae found in the Peruvian Province; (a) Acanthopleura echinata (Antofagasta, scale bar $=30 \mathrm{~mm}$ ), (b) Enoplochiton niger (Coquimbo, scale bar $=20 \mathrm{~mm}$ ), (c) Chaetopleura benaventei (Talcahuano, scale bar $=10 \mathrm{~mm}),(\mathbf{d})$ C. peruviana (Coquimbo, scale bar $=10 \mathrm{~mm}),(\mathbf{e})$ Calloplax vivipara (Coquimbo, scale bar $=5 \mathrm{~mm}$ ), (f) Ischnochiton pusio (Valparaiso, scale bar $=5 \mathrm{~mm})$, (g) I. stramineus (El Sauce, scale $\mathrm{bar}=5 \mathrm{~mm}$ ), (h) Plaxiphora aurata (Valdivia, scale bar $=10 \mathrm{~mm}$ ). Photographs credits: C.M. Ibáñez and M.C. Pardo-Gandarillas.

richness, relative abundance, and evenness) showed significant differences between ecoregions (PERMANOVA, $0.108<F<1.607 ; P>0.05)$.

Neither the ordinary least square regression analysis (OLS) nor the spatial autoregressive model (SAR) evidenced significant relationships between abundance, richness and eveness with the environmental variables evaluated (Table 2$)$, due to a high spatial autocorrelation $(\rho=0.969)$. Only species composition (Jaccard) was significant related with temperature and salinity (Table 2 ).

Overall, most chitons were small (18 species; $<50 \mathrm{~mm} \mathrm{TL}$ ), whith only three species (Acanthopleura echinata, Chiton magnificus and Enoplochiton niger; see Online Appendix Table S2, Fig. 7) corresponding to large chitons $(>50 \mathrm{~mm} \mathrm{TL})$. Significant differences in chiton body lengths were found to be structured by species and ecoregions, with significant interactions between most factors (Table 3 ). The year was the only factor without significant differences (Table 3). However, species was the only factor that explained a high proportion of deviance (56\%; see Table 3). Mean minimum segment lengths in each locality were heterogeneous (59.1-88.8 $\mathrm{mm}$ ), being higher at northern locations and decreasing through the south (Table S3). Maximum chitons body length at each locality was correlated with mean minimum segment length $(r=0.59, P<0.05)$, suggesting that in places with larger chitons they are highly segregated by size. Body size ratios were highly variable (0.0-4.6) and showed significant differences from a random assemblage that was not structured by competition only in some localities, where we suggest some evidence of competition by size overlap at local scale (Table S3).

\section{Discussion}

Our results showed an absence of a latitudinal gradient in abundance and diversity of coastal polyplacophorans in the Peruvian Province, supporting prior results on this coastline $e^{21-24}$. However, the size structure abruptly changed along the coast as a consequence of changes in the latitudinal taxonomic composition. These findings agree with previous descriptions ${ }^{37-39}$ and suggest that species assemblages do conform to the biogeographic province they inhabit, similar to what has been described in many other SE Pacific marine invertebrate species such as crustaceans, molluscs and echinoderms ${ }^{12,15,16}$. 


\begin{tabular}{|c|c|c|c|c|c|c|c|c|c|c|c|c|}
\hline \multirow[b]{2}{*}{ Species/Ecoregion } & Callao & Arica & Iquique & Antofagasta & Huasco & Coquimbo & $\begin{array}{l}\text { El } \\
\text { Sauce }\end{array}$ & \begin{tabular}{|l} 
Los \\
Vilos
\end{tabular} & Valparaiso & Pichilemu & Talcahuano & Valdivia \\
\hline & \multicolumn{4}{|c|}{ Humboldtian } & \multicolumn{5}{|c|}{ Central Chile } & \multicolumn{3}{|l|}{ Araucanian } \\
\hline Acanthopleura echinata & 7.5 & 3 & 6.9 & 3 & 4 & 2.6 & & 5.5 & 5.3 & 7.4 & 1.8 & \\
\hline Callistochiton pulchellus & & & 7.9 & & & & & & & & & \\
\hline Calloplax vivipara & & & 0.3 & & & 0.3 & 1.9 & 0.8 & 2.1 & & & \\
\hline Chaetopleura benaventei & & & & & & & & & & & 0.9 & 2.8 \\
\hline Chaetopleura hennahi & 1.5 & & & & & & & & & & & \\
\hline Chaetopleura peruviana & 1 & 0.5 & 1.5 & 0.3 & 2.4 & 3.8 & 5.1 & 0.6 & 4.8 & 0.5 & 0.6 & 3.3 \\
\hline Chiton barnesii & & & & 0.4 & 2.7 & 2.9 & 12 & 0.3 & & & & 0.3 \\
\hline Chiton cumingsii & 64 & 12 & 13 & 1.8 & 24 & 14 & 4.3 & 42 & 18 & 0.6 & 8.8 & 1.3 \\
\hline Chiton granosus & 26 & 14 & 14 & 6.3 & 3.7 & 2.5 & 0.5 & 4.5 & 12 & 12 & 9.5 & 13 \\
\hline Chiton magnificus & & & & & 4.1 & 7.4 & 2.4 & 1.1 & 17 & 5.8 & 13 & 8.5 \\
\hline Enoplochiton niger & 9.5 & 9 & 1.5 & 5 & 6.6 & 3.3 & & & & & & \\
\hline Gallardoia valdiviensis & & & & & & & & & & & & 0.3 \\
\hline Ischnochiton punctulatissimus & & & 6 & 0.1 & & & & & & & & \\
\hline Ischnochiton pusio & & & & 3.6 & 4.4 & 2.6 & 0.3 & 0.6 & 3.6 & & & \\
\hline Ischnochiton stramineus & & & & & & & 1.1 & & & & & \\
\hline Plaxiphora aurata & & & & 0.2 & & & & & 0.5 & & 0.3 & 1 \\
\hline Tonicia calbucensis & & 4.5 & 2 & 1 & 3.4 & 2.8 & 3.8 & 9.4 & 24 & 2.8 & 5.3 & 13 \\
\hline Tonicia chilensis & & & & & 0.3 & & & & 5.3 & 5.3 & 4 & 9.3 \\
\hline Tonicia disjuncta & & & & & & & & 0.8 & 0.3 & & 0.1 & \\
\hline Tonicia fremblyana & 65 & 7.8 & 1.1 & 6 & 0.8 & 0.9 & & & 3.4 & 0.5 & & \\
\hline Tonicia swainsoni & 3 & & & & & & & & & & & \\
\hline \multicolumn{13}{|l|}{ Diversity indices } \\
\hline Abundance (RA) & 177 & 51 & 63 & 37 & 56 & 42 & 32 & 74 & 96 & 35 & 44 & 52 \\
\hline Richness (S) & 8 & 7 & 10 & 11 & 11 & 11 & 9 & 10 & 12 & 8 & 10 & 10 \\
\hline Evenness (J) & 0.70 & 0.88 & 0.86 & 0.79 & 0.80 & 0.86 & 0.81 & 0.61 & 0.83 & 0.80 & 0.78 & 0.80 \\
\hline
\end{tabular}

Table 1. Relative abundance $(\mathrm{RA}=$ chitons/hour/person) and diversity variables $(\mathrm{S}, \mathrm{J})$ of the polyplacophoran species collected in 12 localities along the Peruvian Province $\left(12^{\circ} \mathrm{S}-39^{\circ} \mathrm{S}\right)$.

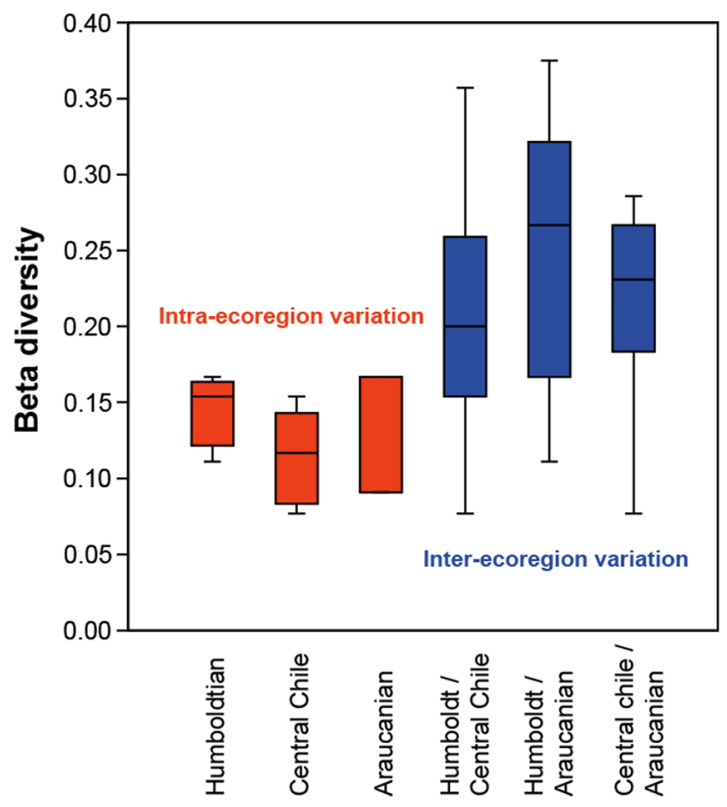

Figure 4. Beta-diversity variation at intra (red plots) and inter-ecoregions (blue plots) levels along the Peruvian Province.

The Peruvian Province has a diversity of chitons similar to that observed in rocky shore ecosystems around the Southeastern Pacific, Baja California and Costa Rica, where up to 12 species of chitons have been reported per site $^{35,40,41}$. In the other hand, the lower diversity observed in tropical areas such as Ecuador and northern Peru, 

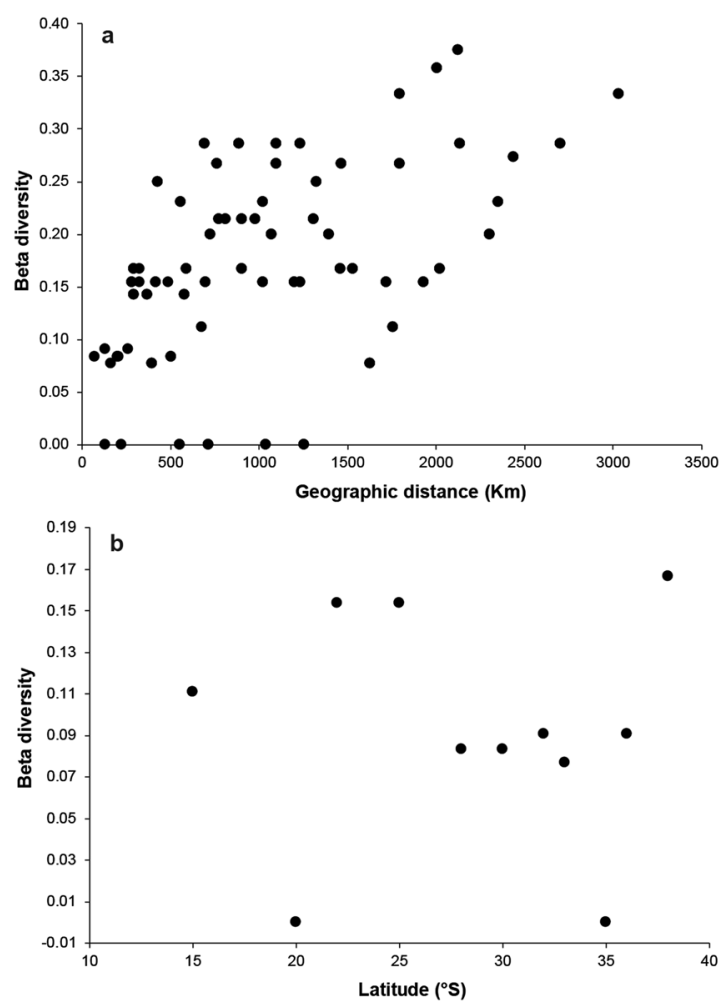

Figure 5. Relationship between beta-diversity and; (a) geographic distance (kms), and (b) latitude ( $\left.{ }^{\circ} \mathrm{S}\right)$ among sampling localities along the Peruvian Province.

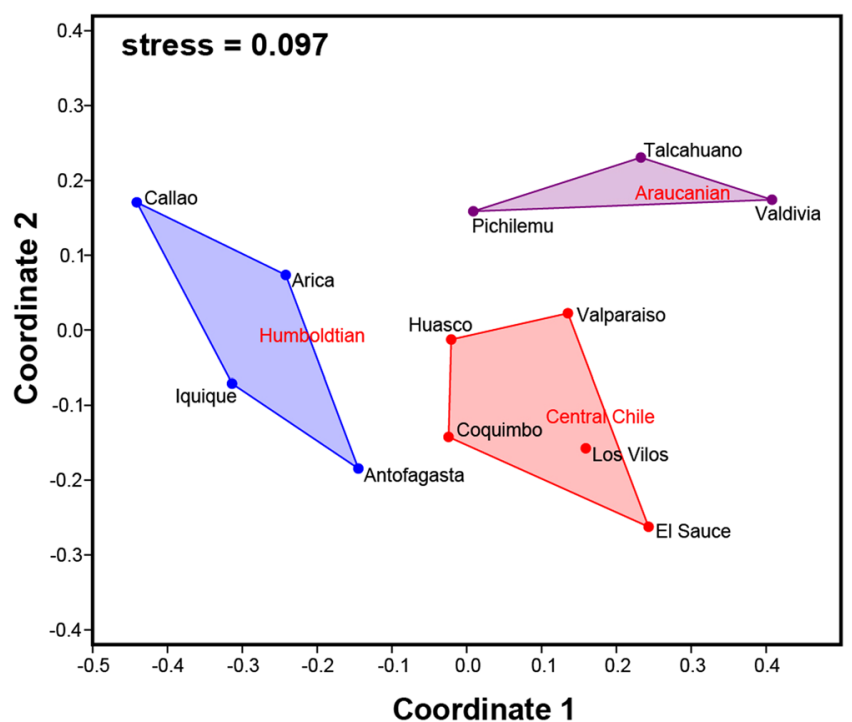

Figure 6. Non-metric Multidimensinal Scaling (nMDS) of chiton assemblages from the Peruvian Province using Jaccard similarity.

would be associated with the low diversity of seaweeds and the scarce rocky ecosystems ${ }^{42}$. It is well known that chitons prefer hard substrata on rocky shores, where some species may be found in high abundances ${ }^{29,37}$.

As shown here, nearby localities tended to have similar species, with composition varying significantly as the distance between localities increased. This same pattern has been observed in subtidal and intertidal fishes ${ }^{42}$ as well as in benthic communities ${ }^{21-23,43-46}$. In this context, Beta diversity (in addition to have the component of species replacement) can also be evaluated from the perspective of similarity between habitats or species' nestedness ${ }^{47,48}$. In the case of the SEP chitons, replacement did not show a latitudinal pattern since these species rarely have small geographical ranges, and dissimilarity between close localities remained low through the latitudinal gradient. The highest species replacement occurred towards the northern part of Central Chile ecoregion 


\begin{tabular}{|c|c|c|c|c|c|c|}
\hline & \multicolumn{3}{|l|}{ OLS } & \multicolumn{3}{|l|}{ SAR } \\
\hline & b & $\mathbf{r}^{2}$ & P-value & b & $\mathbf{r}^{2}$ & P-value \\
\hline \multicolumn{7}{|l|}{ Evenness } \\
\hline Chlorophyll-a & 0.003 & 0.013 & 0.720 & 0.008 & 0.303 & 0.509 \\
\hline Temperature & 0.007 & 0.179 & 0.576 & 0.004 & 0.100 & 0.807 \\
\hline Salinity & 0.014 & 0.015 & 0.975 & -0.004 & 0.303 & 0.938 \\
\hline \multicolumn{7}{|l|}{ Richness } \\
\hline Chlorophyll-a & -0.190 & 0.163 & 0.636 & -0.108 & 0.476 & 0.245 \\
\hline Temperature & -0.169 & 0.053 & 0.954 & -0.018 & 0.517 & 0.747 \\
\hline Salinity & -0.585 & 0.064 & 0.414 & -0.695 & 0.628 & 0.436 \\
\hline \multicolumn{7}{|c|}{ Relative abundance (RA) } \\
\hline Chlorophyll-a & -5.396 & 0.053 & 0.650 & -6.104 & 0.167 & 0.475 \\
\hline Temperature & -1.361 & 0.001 & 0.691 & 7.247 & 0.171 & 0.975 \\
\hline Salinity & -2.482 & $<0.001$ & 0.992 & 0.493 & 0.170 & 0.975 \\
\hline \multicolumn{7}{|c|}{ Composition (Jaccard) } \\
\hline Chlorophyll-a & -0.026 & 0.149 & 0.385 & -0.024 & 0.647 & 0.084 \\
\hline Temperature & -0.096 & 0.827 & $<0.001$ & -0.104 & 0.933 & $<0.001$ \\
\hline Salinity & -0.309 & 0.857 & $<0.001$ & -0.301 & 0.851 & $<0.001$ \\
\hline
\end{tabular}

Table 2. Summary of regression analyses; Ordinary Least Square Regression (OLS) and Spatial Autoregressive Model (SAR) for the relationships between diversity $\left(12^{\circ} \mathrm{S}-36.8^{\circ} \mathrm{S}\right)$ and Chlorophyll-a, Temperature, and Salinity. *Significant p-values $<0.05$.

(Huasco and Coquimbo) and the southern end of the Peruvian Province (Valdivia), being evidenced as a direct relationship between geographic distance and Beta diversity.

The taxonomic composition variation of chiton assemblages along the sampled localities was reflected in the faunistic groups supported by the nMDS analysis. Variation in the assemblages' composition was associated to temperature and salinity gradient along the Peruvian Province. Also, the concordance of three faunal groups with some biogeographic breaks was evident, similar to what has been documented in other coastal invertebrates ${ }^{27}$. Some chiton species showed strong endemism, being unique in the Humboldtian ecoregion (e.g. Callistochiton pulchellus, Chaetopleura hennahi, Ischnochiton punctulatissimus, Tonicia swainsoni), while others were exclusive to the Araucanian ecoregion (e.g. Chaetopleura benaventei, Gallardoia valdiviensis). Those species strongly contributed to the differences in species composition. Contrary to such patterns, some chiton species also inhabited different ecoregions (e.g. Acanthoplerura echinata, Chiton granosus, C. cumingsii, T. calbucensis and Chaetopleura peruviana) maintaining the low levels of replacement observed among localities.

For most intertidal invertebrates along the SEP, sea surface temperature and salinity have been shown to play important roles ${ }^{15,20,21,49}$, contrasting to our findings where no significant correlations with overall chiton diversity where observed. The Humboldt ecosystem is characterized by coastal upwelling in Peru and Chile, and is tightly related to the spatial and temporal dynamics of coastal environments ${ }^{15,50}$. In Chile, two main regions of coastal upwelling have been detected, one in the Mejillones Peninsula (northern Antofagasta; $23^{\circ} \mathrm{S}$ ) and the other between Punta Lengua de Vaca and Punta Pájaros (southern Coquimbo; $\left.\sim 30^{\circ} \mathrm{S}\right)^{15,50}$. Accordingly, these sites evidenced the higher richness and diversity of chitons found between Antofagasta and Valparaiso, localities exhibiting maximum levels of upwelling and productivity. However, chitons diversity was not correlated with chlorophyll-a (an indicator of upwelling events in the HCS) but would be more related to the local availability of favorable habitats (i.e. rocky shores) and food ${ }^{42}$, rather than to environmental variables. Along the Humboldt Current System, the sandy beaches are also frequent ${ }^{15}$, representing unsuitable habitat for chitons. These heterogeneous stretches of beaches, combined with rocky shores, could explain the heterogeneous pattern and the absence of a cline of diversity of chitons found in this study. In fact, it has been suggested that local and small-scale processes could be determinants of the diversity and composition of intertidal communities in Chile, at least between Arica and Valparaíso ${ }^{23}$.

Chiton body lengths showed a high spatial variability and a latitudinal cline in assamblage structure. In northern localities of the Humboldtian and Central Chile ecoregions, assamblages were composed by large and small species, but in southern localities of the Araucanian ecoregion assamblages were composed only by medium and small species. These changes in body size structure were related to changes in species composition. The largest species ( $>100 \mathrm{~mm}$; E. niger and A. echinata, Table S2) inhabit from Coquimbo and Talcahuano through northern localities, respectively ${ }^{39}$. Intertidal chitons are generally thought to be larger than subtidal and deep-sea species ${ }^{51}$, and Southeastren Pacific chitons larger than closely-related species from other ecosystems elsewere, excepting for North Pacific ${ }^{52}$. The evolutionary colonization of the intertidal by chitons increased the competition among them and among other movile invertebrates such as limpets, needing bigger sizes to competitively exclude interspecif$i_{c}{ }^{52,53}$. In central Chile, the largest chitons inhabit zones of high energy on the lower intertidal, while small and juveniles coexist in protected zones in high intertidal zones ${ }^{37}$. This pattern suggests certain kind of competition or niche partitioning among chitons and among other invertebrates, since species of similar body size might not be able to coexist because they overlap too much in the use of shared resources ${ }^{11}$. However, it should be noted that different species of chitons, are known to have different diets and niches. For example, there is evidence to 


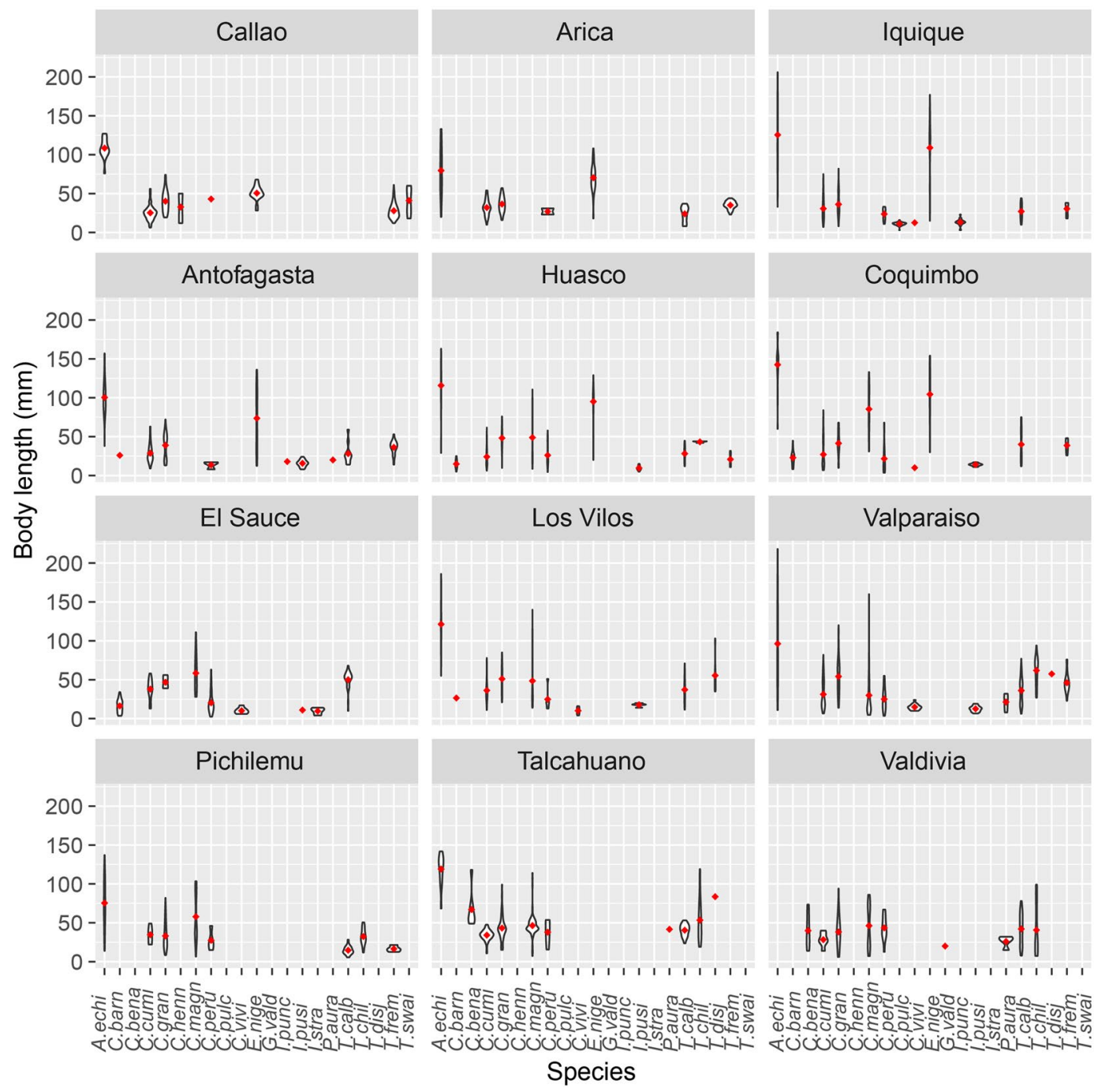

Figure 7. Violin plots by locality and species of chitons body length ( $\mathrm{mm}$ ) from the Peruvian Province. Abbreviations: A. echi: Acanthopleura echinata, C. barn: Chiton barnesii, C. bena: C. benaventei, C. cumi: C. cumingsii, C. gran: C. granosus, C. magn: C. magnificus, C. peru: Chaetopleura peruviana, C. henn: C. hennahi, C. vivi: Calloplax vivipara, E. nige: Enoplochiton niger, G. vald: Gallardoia valdiviensis, I. punc: Ischnochiton punctulatissimus, I. pusi: I. pusio, I. stra: I. stramineus, P. aura: Plaxiphora aurata, T. calb: Tonicia calbucencis, T. chil: T. chilensis, T. disj: T. disjuncta, T., frem: T. fremblyana, T. swai: swainsoni.

\begin{tabular}{|l|l|l|l|l|l|}
\hline & D.F. & Deviance & F & P & \%Deviance \\
\hline NULL & 4724 & 4859186 & & & \\
\hline Ecoregion & 2 & 2747 & 3.236 & 0.0394 & 0.06 \\
\hline Year & 1 & 92 & 0.217 & 0.6409 & 0.002 \\
\hline Species & 19 & 2722337 & 337.630 & $<0.05$ & 56.02 \\
\hline Ecoregion:Year & 2 & 16832 & 19.831 & $<0.05$ & 0.35 \\
\hline Ecoregion:Species & 19 & 88788 & 11.011 & $<0.05$ & 1.83 \\
\hline Year:Species & 16 & 33757 & 4.971 & $<0.05$ & 0.69 \\
\hline Ecoregion:Year:Species & 14 & 20878 & 3.514 & $<0.05$ & 0.43 \\
\hline
\end{tabular}

Table 3. Summary of GLM analyses for the relationships between body size and ecoregions, year, and species.

suggest that the radiation of large bodied Mopalia species in the NE Pacific was driven by niche partitioning to avoid direct competition ${ }^{54}$. Our results of body size ratio and minimum segment length overlap agreed with this hypothesis, since were different from body size simulated data in absence of competition. Another evidence of competition among chitons comes from diet, as several Chilean chitons overlap their diet resources among species and between other intertidal grazers, suggesting a strong competition (e.g. Fissurella spp. and Scurria spp. ${ }^{33}$ ). 
Overall, this work represents the first faunistic and ecological description of polyplacophoran assemblages inhabiting along the Humboldt Current System, providing critical information for an adequate characterization of biodiversity, conservation and potential management strategies in this area, as 3 of the 21 species recorded correspond to artisanally-exploited resources in Chile and Peru.

\section{Methods}

Polyplacophoran samplings were carried out in 12 localities during 2013-2016, between Callao (Peru; $12^{\circ} \mathrm{S}$ ) and Valdivia (Chile; $39^{\circ} \mathrm{S}$ ) (Fig. 1a), encompassing more than $2,500 \mathrm{~km}$ of coastline including three of the four previously mentioned ecoregions of the Peruvian Province (i.e. Humboldtian, Central Chile and Araucanian). Chitons were collected during low tide for a period of one to three hours, sampling on average 4 days per locality. Intertidal species were sampled by 1 to 3 people, while subtidal species by 1 to 2 divers through snorkelling at depths up to $5 \mathrm{~m}$. The collected species were relaxed with $5 \%$ ethanol with sea water, flattened and preserved in $96 \%$ ethanol for further genetic analyses. Once in the laboratory, the total length ( $\mathrm{mm}$, including the girdle) of each chiton was measured to perform comparissons among species, ecoregions and years. In order to standardize the sampling effort, a relative abundance (RA) index was estimated, corrected by sampling time and number of people ( $\mathrm{RA}=\mathrm{n}^{\circ}$ chitons/hour/person). Species identification was performed visually under stereomicroscopy using descriptions and taxonomic keys ${ }^{55-58}$.

To determine whether the RA matrix of species richness is representative of local diversity, a rarefaction curve $\mathrm{e}^{59}$ was calculated for each locality. The expected number of species was estimated using the Chao-1 algorithm ${ }^{59}$, based on relative abundance.

In each locality, species richness $(\mathrm{S})$ and evenness $(\mathrm{J})$ were estimated using the RA data. To evaluate the replacement degree in species composition between localities and ecoregions, beta diversity was estimated using the Williams index ${ }^{60}$ defined as changes species composition with distance ${ }^{61}$. Correlation between geographical distance $(\mathrm{km})$ and beta diversity was determined using the Mantel test with 5,000 permutations ${ }^{62}$.

Similarity between chiton assemblages was evaluated using a non-metric Multidimensinal Scaling (nMDS) ${ }^{63}$ performed with presence-absence data through Jaccard similarities. Differences in diversity variables and species composition between ecoregions were evaluated with one-way PERMANOVA using 10,000 permutations ${ }^{64}$. Subsequently, to determine which species differed significantly between-groups, a Percentage Similarity Analysis (SIMPER) was used ${ }^{63}$. Environmental variables such as chlorophyll-a (as a proxy of productivity $\left[\mathrm{mg} / \mathrm{m}^{3}\right]$ ), sea surface temperature $\left[\mathrm{SST},{ }^{\circ} \mathrm{C}\right]$ and salinity $[\mathrm{PSU}]$ were used to test their relationship with different diversity variables and composition using ordinary linear regressions (OLS) and spatial autoregressive models (SAR), both performed in the software SAM v.4.0 ${ }^{51}$. These environmental data (monthly averages 2000-2014) were obtained from the Bio-Oracle v2.0 database (http://www.oracle.ugent.be/) through the DIVA-GIS v.7.5 software ${ }^{65}$. Rarefaction curves, Diversity, Mantel test, nMDS, SIMPER and PERMANOVA analyses were performed in PAST v.3.22 statistical package ${ }^{66}$.

Chiton body length structure was compared between species, ecoregions and years using Generalized Linear Model (GLM) implemented in the statistical software R v 3.6.1 ${ }^{67}$ In order to explore the possibility of competition, we estimated body size overlap between species in each locality, we generated 5,000 random matrices to create a random size assemblage in the software ECOSIM v7.7268. As size overlap metric, we used the minimum segment length (calculated as the difference in body sizes of two adjacent species) and absolute size differences for each locality. The minimum segment length corresponded to Hutchinson's hypothesis, which stated that a minimum spacing between species is necessary for coexistence. The standardized effect size (SES) of the body size ratio, was calculated as: observed index - mean (simmulated indices)/standard deviation (simulated indices). If SES was greater than 2 or less than -2 , it was considered as statistically significant with a probability $<0.05^{68,69}$.

Received: 10 April 2019; Accepted: 11 October 2019;

Published online: 04 November 2019

\section{References}

1. Willig, M. R., Kaufman, D. M. \& Stevens, R. D. Latitudinal gradients of biodiversity: patterns, process, scale, and synthesis. Annu. Rev. Ecol. Evol. Syst. 34, 273-309 (2003)

2. Grime, J. P. Competitive exclusion in herbaceous vegetation. Nature 242, 344-347 (1973).

3. Grime, J. P. Plant strategies and vegetation processes. (John Wiley and Sons, 1979).

4. Huston, M. A. A general hypothesis of species diversity. Am. Nat. 113, 81-101 (1979).

5. Coleman, B. D., Mares, M. A., Willig, M. R. \& Hsieh, Y. H. Randomness, area, and species richness. Ecology 63, 1121-1133 (1982).

6. Rosenzweig, M. L. Species diversity in space and time. (Cambridge University Press, 1995).

7. Wright, D. H. Species-energy theory: an extension of species-area theory. Oikos 41, 496-506 (1983).

8. Hutchinson, G. E. Homage to Santa Rosalia or why are there so many kinds of animals? Am. Nat. 93, 145-159 (1959).

9. Simberloff, D. \& Boecklen, W. Santa Rosalia reconsidered: size ratios and competition. Evolution 35, 1206-1228 (1981).

10. Wiens, J. A. On size ratios and sequences in ecological communities: Are there no rules? Annales Zoologici. Fennici. 19, 297-308 (1982).

11. Gotelli, N. J., \& Graves, G. R. Null models in ecology. Smithsonian Institution (1996).

12. Camus, P. A. Biogeografía marina de Chile continental. Rev. Chil. Hist. Nat. 74, 587-617 (2001).

13. Astorga, A., Fernández, M., Boschi, E. E. \& Lagos, N. Two oceans, two taxa and one model of development: latitudinal diversity patterns of South American crabs and test for possible causal processes. Ecol. Lett. 6, 1-18 (2003).

14. Valdovinos, C., Navarrete, S. A. \& Marquet, P. A. Mollusk species diversity in the Southeastern Pacific: why are there more species towards the pole? Ecography 26, 139-144 (2003).

15. Thiel, M. et al. The Humboldt Current System of northern and central Chile. Oceanographic processes, ecological interactions and socioeconomic feedback. Ocean. Mar. Biol. Annu. Rev. 45, 195-344 (2007).

16. Ibáñez, C. M., Camus, P. A. \& Rocha, F. J. Diversity and distribution of cephalopod species off the coast of Chile. Mar. Biol. Res. 5, 374-384 (2009) 
17. Fernández, M., Astorga, A., Navarrete, S. A., Valdovinos, C. \& Marquet, P. A. Deconstructing latitudinal species richness patterns in the ocean: does larval development hold the clue? Ecol. Lett. 12, 601-611 (2009).

18. Lee, M. R. \& Riveros, M. Latitudinal trenes in the species richness of free-living marine nematodo assemblages from exponed sandy beaches along the coast of Chile (18-42 ${ }^{\circ}$ S). Mar. Ecol. 33, 317-325 (2012).

19. Sigwart, J. D. What Species Mean: A User's Guide to the Units of Biodiversity. 242 pp. (C.R.C. Press, 2018).

20. Broitman, B. R., Navarrete, S. A., Smith, F. \& Gaines, S. D. Geographic variation of southeastern Pacific intertidal communities. Mar. Ecol. Prog. Ser. 224, 21-34 (2001).

21. Broitman, R. B. et al. Geographic variation in diversity of wave exposed rocky intertidal communities along central Chile. Rev. Chil. Hist. Nat. 84, 143-154 (2011)

22. Rivadeneira, M. M., Fernández, M. \& Navarrete, S. A. Latitudinal trends of species diversity in rocky intertidal herbivore assemblages: spatial scale and the relationship between local and regional species richness. Mar. Ecol. Prog. Ser. 245, 123-131 (2002).

23. Camus, P. A. Diversidad, distribución y abundancia de especies en ensambles intermareales rocosos. Rev. Biol. Mar. Oceanogr. 43, 615-627 (2008).

24. Sepúlveda, R. D., Camus, P. A. \& Moreno, C. A. Diversity of faunal assemblages associated with ribbed mussel beds along the South American coast: relative roles of biogeography and bioengineering. Mar. Ecol. 37, 943-956 (2016).

25. Jablonski, D. et al. Out of the tropics, but how? Fossils, bridge species, and thermal ranges in the dynamics of the marine latitudinal diversity gradient. Proc. Nat. Acad. Sci. 110, 10487-10494 (2013).

26. Brattström, H. \& Johanssen, A. Ecological and regional zoogeography of the marine benthic fauna of Chile. Sarsia 68, 289-339 (1983).

27. Lancellotti, D. A. \& Vásquez, J. A. Zoogeografía de macroinvertebrados bentónicos de la costa de Chile: contribución para la conservación marina. Rev. Chil. Hist. Nat. 73, 99-129 (2000).

28. Aguilera, M. A. Cirripedios en la dieta del molusco herbívoro Chiton granosus Frembly, 1827 (Mollusca, Placophora) presente en el intermareal rocoso de Iquique, norte de Chile. Invest. Mar. 33, 109-113 (2005).

29. Aguilera, M. A. \& Navarrete, S. A. Effects of Chiton granosus (Frembly, 1827) and other molluscan grazers on algal succession in wave exposed mid-intertidal rocky shores of central Chile. J. Exp. Mar. Biol. Ecol. 349, 84-98 (2007).

30. Sanhueza, A. G., Navarrete, A. H., Opazo, L. F. \& Camus, P. A. Caracterización trófica del placóforo intermareal Enoplochiton niger en el norte de Chile: variación ambiental y patrones dietarios a nivel local y región. Rev. Chil. Hist. Nat. 81, 533-546 (2008).

31. Camus, P. A., Daroch, K. \& Opazo, L. F. Potential for omnivory and apparent intraguild predation in rocky intertidal herbivore assemblages from northern Chile. Mar. Ecol. Prog. Ser. 361, 35-45 (2008).

32. Camus, P. A., Navarrete, A. H., Sanhueza, A. G. \& Opazo, L. F. Trophic ecology of the chiton Acanthopleura echinata on Chilean rocky shores. Rev. Chil. Hist. Nat. 85, 123-135 (2012).

33. Camus, P. A., Arancibia, P. A. \& Ávila-Thieme, M. I. A trophic characterization of intertidal consumers on Chilean rocky shores. Rev. Biol. Mar. Oceanogr. 48, 431-450 (2013).

34. Eernisse, D. J. Chitons in Encyclopedia of tidepools and rocky shores (eds Denny, M. W. \& Gaines, S. D.) 127-133 (University of California Press, 2007).

35. Schwabe, E., Försterra, G., Häussermann, V., Melzer, R. R. \& Schrödl, M. Chitons (Mollusca: Polyplaophora) from the southern Chilean Comau Fjord, with reinstatement of Tonicia calbucensis Plate, 1897. Zootaxa 1341, 1-27 (2006).

36. Reid, D. G. \& Osorio, C. The shallow-water marine mollusca of the Estero Elefantes and Laguna San Rafael, southern Chile. Bull. Mus. Nat. Hist. Zool. 66, 109-146 (2000).

37. Otaíza, R. D. \& Santelices, B. Vertical distribution of chitons (Mollusca: Polyplacophora) in the rocky intertidal zone of central Chile. J. Exp. Mar. Biol. Ecol. 86, 229-240 (1985).

38. Aldea, C. \& Valdovinos, C. Moluscos del intermareal rocoso del centro-sur de Chile ( $\left.36^{\circ}-38^{\circ} \mathrm{S}\right)$ : Taxonomía y clave de identificación. Gayana 69, 364-396 (2005)

39. Araya, J. F. \& Araya, M. E. The shallow-water chitons (Mollusca, Polyplacophora) of Caldera, Region of Atacama, northern Chile. Zoosyst. Evol. 91, 45-58 (2015).

40. García-Ríos, C. I. \& Álvarez-Ruiz, M. Comunidades de quitones (Mollusca: Polyplacophora) de la Bahía de La Paz, Baja California Sur, México. Rev. Biol. Trop. 55, 177-182 (2007).

41. Jörger, K. M., Meyer, R. \& Wehrtmann, I. S. Species composition and vertical distribution of chitons (Mollusca: Polyplacophora) in a rocky intertidal zone of the Pacific coast of Costa Rica. J. Mar. Biol. Ass. U.K. 88, 807-816 (2008).

42. Ibáñez, C., Sellanes, J. \& Pardo-Gandarillas, M. C. Diversidad de poliplacóforos tropicales del sur de la Provincia Panameña. Lat. Am. J. Aquat. Res. 44, 807-814 (2016).

43. Navarrete, A. H., Lagos, N. A. \& Ojeda, F. P. Latitudinal diversity patterns of Chilean coastal fishes: searching for causal processes. Rev. Chil. Hist. Nat. 87, 1-11 (2014).

44. Paterson, G. L., Wilson, G. D., Cosson, N. \& Lamont, P. A. Hessler and Jumars (1974) revisited: abyssal polychaete assemblages from the Atlantic and Pacific. Deep Sea Res. Part II 45, 225-251 (1998).

45. Clarke, A. \& Lidgard, S. Spatial patterns of diversity in the sea: bryozoan species richness in the North Atlantic. J. Anim. Ecol. 69, 799-814 (2000).

46. Ellingsen, K. E. Biodiversity of a continental shelf soft-sediment macrobenthos community. Mar. Ecol. Prog. Ser. 218, 1-15 (2001).

47. Ellingsen, K. E. Soft-sediment benthic biodiversity on the continental shelf in relation to environmental variability. Mar. Ecol. Prog. Ser. 232, 15-27 (2002).

48. Ricotta, C. \& Burrascano, S. Beta diversity for functional ecology. Preslia 80, 61-71 (2008).

49. Baselga, A. Partitioning the turnover and nestedness components of beta diversity. Glob. Ecol. Biogeogr. 19, 34-143 (2010).

50. Figueroa, D. Forcing of physical exchanges in the nearshore Chilean ocean. In The oceanography and ecology of the nearshore and bays in Chile (eds Castilla, J. C. \& Largier, J. L.) 31-43 (Ediciones Universidad Católica de Chile, 2002).

51. Rangel, T. F., Diniz-Filho, J. A. F. \& Bini, L. M. SAM: a comprehensive application for spatial analysis in macroecology. Ecography 33, $46-50(2010)$

52. Watters, G. T. Utilization of a simple morphospace by polyplacophorans and its evolutionary implications. Malacologia 33, 221-240 (1991).

53. Montecino, V. et al. Bio-physical interactions off western South America (6,E). In The Sea (eds Robinson, A. R. \& Brink, K. H.) 329-390 (Harvard University Press, 2005).

54. Vermeij, G. J. The evolution of gigantism on temperate seashores. Biol. J. Linn. Soc. 106, 776-93 (2012).

55. Bullock, R. C. The genus Chiton in the New World (Polyplacophora: Chitonidae). Veliger 31, 141-191 (1988)

56. Kaas, P., Van Belle, R. A. \& Stack, H. Monograph of living chitons (Mollusca: Polyplacophora) in Vol. 6, Suborder Ischnochitonina (concluded); Schizochitonidae \& Chitonidae, Additions to Vol. 1-5. (Koninklijke Brill N.V., 2006).

57. Schwabe, E. A. Polyplacophora - Chitones (Quitones). In Fauna marina bentónica de la Patagonia Chilena (eds Haüssermann, V. \& Försterra, G.) 390-424 (Nature in Focus, 2009).

58. Ibáñez, C. M. et al. Phylogeny, divergence times, and species delimitation of Tonicia (Polyplacophora: Chitonidae) from the Eastern Pacific Ocean. Zool. J. Linnean. Soc. 186, 915-933, https://doi.org/10.1093/zoolinnean/zlz006 (2019).

59. Colwell, R. K., Mao, C. X. \& Chang, J. Interpolating, extrapolating, and comparing incidence-based species accumulation curves. Ecology 85, 2717-2727 (2004)

60. Koleff, P., Gaston, K. J. \& Lennon, J. J. Measuring beta diversity for presence-absence data. J. Anim. Ecol. 72, 367-382 (2003). 
61. Condit, R. et al. Beta-diversity in tropical forest trees. Science 295, 666-669 (2002).

62. Mantel, N. The detection of disease clustering and a generalized regression approach. Cancer Res. 27, 209-220 (1967).

63. Clarke, K. R. Nonparametric multivariate analyses of changes in community structure. Aust. J. Ecol. 18, 117-143 (1993).

64. Anderson, M. J. A new method for non-parametric multivariate analysis of variance. Austral Ecol. 26, 32-46 (2001).

65. Hijmans, R. J., Guarino, L., Cruz, M. \& Rojas, E. Computer tools for spatial analysis of plant genetic resources data: 1. DIVA-GIS. Plant Genet. Resour. News. 127, 15-19(2001).

66. Hammer, Ø., Harper, D. A. T. \& Ryan, P. D. PAST: Paleontological statistics software package for education and data analysis. Palaeontol. Electron. 4, 1-9 (2001).

67. R Core Team. R. A language and environment for statistical computing. R Foundation for Statistical Computing, Vienna, Austria. http://www.R-project.org/ (2018).

68. Gotelli, N. J. \& Entsminger, G. L. EcoSim: Null models software for ecology. Version 5.0. Acquired Intelligence Inc. \& Kesey-Bear, http://homepages.together.net/ gentsmin/ecosim.htm (2000).

69. Sigwart, J. D. \& Schwabe, E. Anatomy of the many feeding types in polyplacophoran molluscs. Invert, Zool. 14, 205-216 (2017).

\section{Acknowledgements}

We would like to thank Boris Sirenko and Douglas Eernisse for their help during sampling and species identification. We further thank C. Cornejo, C. Tobar, A. Navarrete, R. Sepúlveda, V. Sanhueza, G. Zapata, A. Cifuentes and J.F. Ruiz who also assisted with field and laboratory work. This study was funded by Fondo Nacional de Desarrollo Científico y Tecnológico research grants 1130266, 1181153 and DI-13-18/REGUNAB, 11181320 awarded to C.M. Ibáñez and C. Pardo-Gandarillas, respectively.

\section{Author contributions}

C.M.I., J.S. and M.C.P.-G. conceived the idea, designed the study, analysed the data, and led the writing of the manuscript; C.M.I., M.C.P.-G., S.A.C., F.I.T., J.S. and J.D.S. collected material; S.A.C., F.I.T., M.W. and J.D.S. helped with writing and provided editorial advice. All authors have read and commented on the manuscript.

\section{Competing interests}

The authors declare no competing interests.

\section{Additional information}

Supplementary information is available for this paper at https://doi.org/10.1038/s41598-019-52395-z.

Correspondence and requests for materials should be addressed to C.M.I.

Reprints and permissions information is available at www.nature.com/reprints.

Publisher's note Springer Nature remains neutral with regard to jurisdictional claims in published maps and institutional affiliations.

Open Access This article is licensed under a Creative Commons Attribution 4.0 International License, which permits use, sharing, adaptation, distribution and reproduction in any medium or format, as long as you give appropriate credit to the original author(s) and the source, provide a link to the Creative Commons license, and indicate if changes were made. The images or other third party material in this article are included in the article's Creative Commons license, unless indicated otherwise in a credit line to the material. If material is not included in the article's Creative Commons license and your intended use is not permitted by statutory regulation or exceeds the permitted use, you will need to obtain permission directly from the copyright holder. To view a copy of this license, visit http://creativecommons.org/licenses/by/4.0/.

(c) The Author(s) 2019 